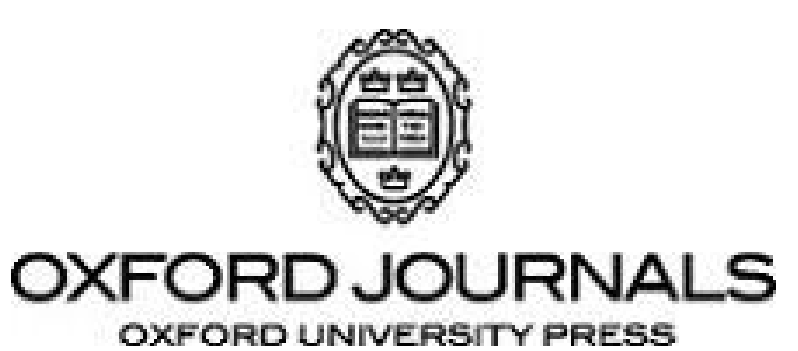

The Review of Economic Studies Ltd.

Inefficiency and the Demand for "Money" in a Sequence Economy: A Correction Author(s): Ross M. Starr

Source: The Review of Economic Studies, Vol. 45, No. 2 (Jun., 1978), p. 391

Published by: Oxford University Press

Stable URL: http://www.jstor.org/stable/2297356

Accessed: 19/07/2011 17:55

Your use of the JSTOR archive indicates your acceptance of JSTOR's Terms and Conditions of Use, available at http://www.jstor.org/page/info/about/policies/terms.jsp. JSTOR's Terms and Conditions of Use provides, in part, that unless you have obtained prior permission, you may not download an entire issue of a journal or multiple copies of articles, and you may use content in the JSTOR archive only for your personal, non-commercial use.

Please contact the publisher regarding any further use of this work. Publisher contact information may be obtained at http://www.jstor.org/action/showPublisher?publisherCode=oup.

Each copy of any part of a JSTOR transmission must contain the same copyright notice that appears on the screen or printed page of such transmission.

JSTOR is a not-for-profit service that helps scholars, researchers, and students discover, use, and build upon a wide range of content in a trusted digital archive. We use information technology and tools to increase productivity and facilitate new forms of scholarship. For more information about JSTOR, please contact support@ jstor.org. 


\title{
Money in a Sequence Economy: A Correction
}

\author{
ROSS M. STARR \\ University of California, Davis
}

In Starrett's [1] elegant and important study, there is an oversight in the statement of Lemma 1 (p. 446). The sense of the inequality in equation (23) and the definition of the interest factor $S_{w}^{n}$ are incorrect as printed. An alternative correct formulation of the Lemma is:

Lemma 1 (corrected). The problem (19) is equivalent to

$$
\left(x_{h}^{w}, y_{h}^{w}\right) \text { maximizes } U^{h}
$$

subject to non-negativity of $c_{h}, x_{h}^{w}, y_{h}^{w}$, and subject to

where

$$
\sum_{w} S_{w}^{n}\left(q^{w} y_{h}^{w}-p^{w} x_{h}^{w}\right) \leqq 0
$$

$$
S_{w}^{n} \equiv \prod_{t={ }_{n}}^{w-1} 1 / S^{t}, \quad \text { for } n \text { an arbitrary base date }(n \leqq b(h)-1) .
$$

The original statement in Starrett [1] differs in the sense of the inequality and by defining $S_{w}^{n}$ as $\prod_{t=n}^{w} S^{t}$. The proof follows as outlined in Starrett [1] with a change in multiplicative constant: "(23) is obtained from (17), (18) by substituting recursively for the $d_{h}^{w}$ in (17) using (18) and multiplying by a constant:" $\prod_{t=n}^{n(h)-1} 1 / S^{t}$. The rest of the proof is identical.

The new definition of $S_{w}^{n}$ is formally very similar to Starrett's and represents what the term was intended to convey. $S_{w}^{n}$ (corrected) $=S^{w} / S_{w}^{n}$ (original). Theorems 2 and 3 follow as before.

First version received November 1976; final version accepted June 1977 (Eds.).

Notation and the numbering of equations are taken from Starrett [1]. I am indebted to Rhonda Price for assistance in research and to David Starrett for a helpful conversation. Errors are my responsibility.

\section{REFERENCE}

[1] Starrett, D, "Inefficiency and the Demand for 'Money' in a Sequence Economy", Review of Economic Studies, 40 (1973), 437-448. 